\title{
Examining the public's exposure to reports about ethnic groups in mainstream Russian media
}

\author{
Anna A. Gladkova ${ }^{\text {aæ}}$, Kseniya A. Korobeinikova ${ }^{\mathrm{b}}$ \\ a Journalism faculty, Lomonosov Moscow State University, Moscow, Russia \\ ${ }^{\mathrm{b}}$ Mail.ru Group, Moscow, Russia \\ *Corresponding author. E-mail: gladkova_a@list.ru
}

\begin{abstract}
This article examines the exposure of Russian public to reports about ethnic groups in current mainstream Russian media by analyzing the amount of such reports today, as well as results of an online survey $(n=1040)$ aimed at revealing to what extent the public is indeed exposed to them by the respondents' own estimations. The survey showed that generally users tend to lack information about ethnicities in mainstream media and demonstrate a certain interest in learning more about other ethnic groups in Russia through media channels. We argue thus that the public's exposure to information about ethnic issues, although relatively high on a quantitative level (i.e., in terms of the actual number of reports), is lower on a qualitative one (i.e., the share of the respondents who actually come across such reports). The paper also reveals a number of tendencies from analyzing users' age groups and their regions of living. In general, we believe that singling out both specifics of the public's exposure to information about ethnicities and the connection between this exposure and the public's attitudes toward ethnicities (which is planned as the second stage of the current research project) may contribute to better understanding of the effects media can have on their audience in terms of agenda-setting and psychological influence. The current research can also be of interest when discussing the role mass media play in building harmonious relationships between representatives of different ethnic groups in a multiethnic society such as the Russian one.
\end{abstract}

Keywords: exposure, ethnic groups, mainstream media, audience, Russia

\section{Introduction}

In a multiethnic and multicultural Russian society, the problem of strengthening relationships between representatives of different ethnic, cultural, and linguistic groups is becoming extremely important today. As the national census of 2010 showed, there are currently more than 190 ethnic groups speaking over 170 lan- 
guages $^{1}$ in the territory of the Russian Federation. It is not surprising that the differences in mentality, culture, traditions, norms, and values of these groups may influence the way people perceive each other and communicate with each other, sometimes making it difficult for representatives of one ethnic group to understand those belonging to another one, and to get along well with them. However, it is quite clear that the differences in mentality, language, and culture are not the only factors affecting intercultural and interethnic communication in such an ethnically diverse society. Numerous studies by ethnologists, psychologists, sociologists, and media and cultural scholars - both domestic and international - have looked into a multitude of other factors that can affect relationships between different ethnic groups in a multicultural Russian society.

If we try to classify these studies roughly into several big thematic blocks, we identify the following clusters:

- $\quad$ studies discussing the role of stereotypes in interethnic conflicts and miscommunication across nations (Verevkin, 2009; Minyar-Belorucheva \& Pokrovskaya, 2012; Mishlanova \& Sirotkina, 2013; Malkova, 2007; Gladkova, 2013b, 2015; Petrova et al., 2014; Contini, 2013; Elchardus \& Spruyt, 2014; Loennqvist et al., 2014; Ivanic, Bates \& Somasundaram, 2014, and others)

- $\quad$ studies focusing on issues of in-group and out-group trust and the impact of trust and other psychological phenomena upon interethnic relations (Alesina \& La Ferrara, 2002; Abanes, Scheepers \& Sterkens, 2014; Gundelach, 2014; Bahry et al., 2005; Allwood, Traum \& Jokinen, 2000, and others)

- $\quad$ studies identifying social prerequisites for interethnic confrontation, such as the degree of diversity in the society (Alesina \& La Ferrara, 2002; Gladkova, 2013a; Matsaganis, Katz \& Ball-Rokeach, 2011; Vartanova, 2005, 2012) and the role of social categorization in provoking conflicts and misunderstanding (Ufkes et al., 2012)

- $\quad$ studies examining personal characteristics and their role in multicultural communication, including respondents' pride in belonging to a certain ethnic group and its influence upon their tolerance toward other ethnic formations (Ward et al., 2006), as well as individuals' level of education, income, and gender and age characteristics, etc.;

- studies discussing issues of migration and the lack of sense of belonging among migrants as a potential risk factor in a multiethnic society (Osin \& Konstantinov, 2014; Bazhenova et al., 2015);

- studies analyzing the role of language and linguistic means, including hate speech, in affecting attitudes toward ethnic groups (Shulumba, 2013; Malkova, 2007).

This list is certainly missing other factors that can possibly influence relationships between different ethnic groups too, since listing all of them would be a lengthy process and require a separate study. 
What we consider to be important to discuss, and what is not always mentioned when it comes to examining interethnic relationships, is the role of mass media in interethnic communication. An interesting question to discuss in this respect is whether mass media have any impact upon people's attitude to ethnic groups different from their own, and if so, how this attitude is created. In our view, this question becomes particularly important in a multiethnic and multicultural society, such as the Russian one, where peaceful co-existence between people belonging to different ethnic groups is not always the case.

As statistical data show, the number of conflicts on ethnic grounds in modern Russia is high: according to the Center for National Conflict Studies, in the period of September, 2013 through March, 2014, there arose 570 conflicts between representatives of different ethnic groups ${ }^{1}$, including both open clashes, such as disturbances in Pugachevo (July 2013) or in Western Birulevo in Moscow (October ,2013), and so-called "distant way" conflicts, which did not necessarily involve actual confrontation in reality but could start in online environments (social media, forums, online chats, etc.) and later on turn into clashes in offline space too. This makes the discussion about factors affecting interethnic relations in Russia (mentality, language, the level of in-group and out-group trust, personal characteristics, social prerequisites, and other aforementioned factors, as well as possibly mass media) particularly up to date.

Previous researchers in this field showed that mass media tend to play a significant role in forming people's attitude toward other ethnicities, conveying values and messages that people may absorb unintentionally (Robert \& Lichter, 1988). Situations when ethnic minorities are underrepresented in media or portrayed in a biased and stereotypical way (Williamson \& DeSouza, 2006; Asamen et al., 2008; Schemer, 2014) may contribute to creating a negative attitude toward other ethnicities too.

These suggestions are supported by fundamental theories, namely agenda-setting and framing ones. According to the agenda-setting theory elaborated in the late 1960s and early 1970s by Maxwell E. McCombs and Donald L. Shaw (McCombs \& Shaw, 1972), there exists a link between what is regularly reported by the media and what people, as consumers of such information, consider important and worth paying attention to. As was later discussed, the media are able to set the agenda, not only in relation to a variety of processes happening at some point (ranking them in order of importance) but also with regard to a specific event or person (in our case, ethnic groups). Obviously, while informing the public of certain facts or phenomena, media cannot provide the public with all the information available (because of limitations in the amount of space in newspapers, or TV and radio time). Instead, they tend to focus the public's attention only on specific aspects or attributes of the material that are most important, in the media's opinion (Weaver, McCombs \& Shaw. 2004; Kazakov, 2014). As a result, a kind of agenda - but in relation to the characteristics of a single object - is built.

Another theory in many ways similar to agenda-setting is framing. It is widely believed now that framing is the process of selecting which aspects of reality jour- 
nalists display, making them more salient in order to formulate certain causal connections, moral interpretations, and recommendations on how to act in relation to a particular situation (Entman, 1993; Scheufele, 2004). Thus it is believed that by drawing the public's attention to specific aspects of the event or the phenomenon, i.e., creating so-called frames, the media significantly determine how readers, viewers, or listeners treat it.

If we assume that media play a significant role in creating people's attitudes toward multiple phenomena in real life through setting agendas and creating frames, an interesting question to discuss would be whether regular exposure to particular phenomena in media would influence the public's attitude toward these phenomena. According to the contact theory elaborated by Gordon W. Allport (1979), regular exposure to people of different backgrounds and ethnicities can lead to less prejudice. Keeping in mind an important role played by the media, we believe that regular exposure to people with different backgrounds and belonging to different ethnic and cultural groupings through media channels (TV and radio programs, publications in newspapers and magazines, as well as the Internet) is likely not only to create the public's agenda in general but also to influence this agenda in a positive or negative way (Malkova, 2007; Makeenko, 2007; Dunas, 2011; Obraztsova, 2014; Gureeva, 2015).

It should be noted that the idea of correlation between media exposure and the public's attitudes and even patterns of behavior has received extensive coverage in the academic literature so far, particularly in multiple studies by psychologists analyzing the correlation between media violence and aggressive behavior (Séguin \& Klimek, 2015; Krahé \& Busching, 2015, and others). In this research project, which we started in 2015, we would like to elaborate on this idea, looking into correlation of the public's exposure to ethnic groups through media channels and the public's attitudes toward these groups (if any). The first thing that we will focus on is an examination of the level of exposure to reports about ethnic groups in mainstream Russian media. In this paper we are going to test the hypothesis that the public's exposure to reports about ethnic groups in mainstream Russian media is relatively high today. While doing that, we will focus on the following key research questions:

(a) whether the public's exposure to such reports is higher on a quantitative or qualitative level, or whether it remains the same on both levels (quantitative level meaning the number of ethnic media and reports on this topic in mainstream Russian media ${ }^{1}$, and qualitative level meaning real exposure of the public to such reports, according to the respondents' own estimations); and

(b) whether the public's exposure to such reports depends on their age groups and regions of living.

As mentioned earlier, this paper focuses mainly on the primary stage of the research we conducted and examines whether Russians are currently exposed to reports about ethnic groups in mainstream media in general or not. During the

1 http://club-rf.ru/thegrapesofwrath/01/ 
second stage of this research project, which is still underway, we will look into the nature of these reports more specifically and will try to define in what way media can influence one's attitude toward ethnic groups; we will discuss the following:

(a) the particular characteristics of the reports, including their tone (positive, negative, neutral), themes, genres, choice of words (including hate speech), style, illustrations (if any), choice of heroes, length, etc.;

(b) the impact reports of different kinds have on the public, as estimated by the public itself (for example, whether interviews with representatives of ethnic groups are likely to have bigger effect on the public than a journalistic essay; whether the use of hate speech and words with negative connotations can create a negative feeling toward the people described, etc.).

When both stages are complete, we expect to find out the following:

(a) whether Russians are generally exposed to reports about ethnic groups in mainstream media today, and how great this exposure is; and

(b) whether the public's attitudes (positive, mostly positive, neutral, mostly negative, negative) toward particular ethnicities depend on the media they are exposed to, as well as the periodicity and nature of this exposure.

The current paper, as outlined earlier, focuses on research objective (a) mainly, while (b) will be discussed in further studies. All in all, we believe that the analysis of the dependency of the public's attitudes toward phenomena covered by the media on the level of their exposure to media can contribute to further understanding of the agenda-setting, framing, and contact theories, as well as the analysis of psychological effects media can have on the public.

\section{Method}

The key methods we used at this stage of the research was the analysis of the number of reports about ethnic issues in Russian mainstream media today, and the online survey ${ }^{1}$ aimed at revealing the public's exposure to reports about ethnic groups in the media, as estimated by the public itself. The chosen methods were expected to help us measure media exposure using the measurement factors suggested by Paul Freedman and Ken Goldstein (1999): the frequency with which information is aired in a particular media market and the quantity of information consuming by a particular respondent.

To start with, we looked into the number of reports about ethnic issues in various Russian-language mainstream media in the spring and summer of 2015; the data are freely available in governmental reports (see, for example, Informatsionnoanaliticheskie materialy $k$ sovmestnomu zasedaniu Soveta pri Prezidente Rossiiskoi Federatsii po mezhnatsionalnym otnosheniyam i Soveta pri Prezidente Rossiiskoi Federatsii po russkomu yazyku, 2015) or previous quantitative studies conducted by domestic scholars (see, for example, Malkova, 2007; Gladkova, 2015). We believe that these data would allow us to first draw very sketchy conclusions about the 
accessibility of information about interethnic relations on a broad scale, and consequently the public's exposure to this information. A simple guess would be the following: the bigger amount of such media, the higher the public's exposure to it. However, we think that the raw number of media outlets, reports outlining ethnic problems, or circulation of media outlets cannot fully reflect the public's exposure to media content, since often people do not consume particular information, even when they have free access to it (because of a lack of interest in this topic, for instance, or other reasons).

That is why we conducted an online survey aimed at revealing how many people are in fact exposed to reports about ethnic issues in current Russian media, by their own estimations. The key criteria for analysis were as follows:

(a) the frequency with which readers or viewers come across information about ethnic groups in mainstream Russian media (very often, often, from time to time, seldom, never, not sure);

(b) the quantity of information received there (i.e., if persons would prefer to see much more information, the same amount, less, or much less (or not sure) on this topic in media);

(c) their basic interest in learning more about ethnic groups through mainstream media (i.e., if persons come across these reports in the media, they will most be likely, probably likely, probably not likely, or unlikely (or not sure) to study them);

(d) the specification of the public's interests (on what topic(s) reports would most likely attract the public's attention: ethnic groups' customs and traditions, history, language, religious faiths, values, and moral codes, or other);

(e) the primary sources of information about ethnic groups (print media, TV and radio programs, the Internet, friends, educational institutions (school, university), etc.), as well as some other factors.

The survey was placed on an open-access platform with daily announcements on two websites of Mail.ru Group company: News@Mail.ru (a news website) and Afisha@Mail.ru (an entertainment website) in the spring and summer of 2015. It should be noted that Mail.ru is one of the biggest portals of Runet (the Russian Internet). The users of this portal constitute $56.1 \%$ of the total number of Runet users, and the portal itself takes the first place among the top 20 desktop Internet websites, according to $\mathrm{TNS}^{1}$. It is also the biggest portal (30.1 million persons and $28.5 \%$ ) by number of average daily visitors.

The total number of respondents we examined was 1040. The sampling is representative for both key groups under analysis: age groups (under 24: 250 persons, 25-44: 470, 45-64: 280, and over 65: 40) and groups according to their region of living (Moscow: 100 persons, St. Petersburg: 40, cities with a population over 1 million: 110 , those with populations of $500,000-1$ million: 80 , those between 250,000 and 500,000: 230, those under 250,000, including villages: 480). We chose stratified sampling while conducting the research, using data on the so-

$1 \quad$ http://screencast.com/t/ZkQb7DqP 
ciodemographic characteristics of Russian Internet users provided by the Public Opinion Fund ${ }^{1}$ and $\mathrm{TNS}^{2}$. Let us note that the sample is limited to two criteria (age and region of living) only due to the availability of data about Internet users' sociodemographic characteristics and the attempt to find out whether there exists any connection between respondents' age, their region of living, and media exposure. When making a statistical analysis of the results, Pearson's chi-square test with Yates's correction was used. Differences were considered significant when $P<0.05$.

\section{Results}

To start with, we found that the number of media outlets devoted to the life of Russian ethnic groups is rather large: there are 692 ethnic media outlets officially registered in the territory of the Russian Federation today; they cover various aspects of the culture, traditions, history, etc. of these groups (Informatsionno-analiticheskie materialy $k$ sovmestnomu zasedaniu Soveta pri Prezidente Rossiiskoi Federatsii po mezhnatsionalnym otnosheniyam i Soveta pri Prezidente Rossiiskoi Federatsii po russkomu yazyku, 2015). The majority of these media are in the languages of the largest ethnic groups ${ }^{3}$ : Tatar, Bashkir, Chuvash, and others. As previous studies show, though, many of these media - particularly print and audiovisual - are produced in several languages, often in the language of the particular ethnic group and in the Russian language (Gilmanova, 2013), which makes them available to both ethnic communities and a broad Russian-speaking audience. Many of them are also distributed on a federal level and/or have online versions, which also contributes to their broad availability to readers (Gladkova, 2015). The number of reports devoted to ethnic issues and interethnic relations in federal Russian-language media is quite high too. As a content analysis carried out by Malkova (2007) and other scholars proves, all-Russian newspapers, for example, Moskovsky Komsomolets, Komsomolskaya Pravda, and Rossiiskaya Gazeta, as well as many federal TV and radio stations (Perviy Kanal, Rossiya 1, Radio Rossii, etc.) aimed at a broad audience pay a good deal of attention to ethnic issues, coverage of ethnic conflicts, stereotypes regarding various ethnicities, etc.

It should be added that the Russian government has undertaken a number of successful steps to make media about ethnic communities and in languages other than Russian available to a broad audience, as well as developing a sensible attitude toward coverage of ethnicities in the media. In this respect, it should be mentioned that it signed the European Charter for Regional or Minorities Languages in 2001; started a joint program of the Council of Europe, the Ministry for Regional Development of the Russian Federation, and the European Commission's "Minorities in Russia: Developing Languages, Culture, Media and Civil Society" in 2009; and opened various institutions, such as the Moscow House of Nationalities, Guild of Interethnic Journalism, Presidential Council for Interethnic Relations in Russia,

http://runet.fom.ru/

http://www.tns-global.ru/

http://www.gks.ru/free_doc/new_site/perepis2010/croc/perepis_itogi1612.htm 
and others (Gladkova, 2015). The significant impact mass media can have upon setting an agenda regarding interethnic relations for media consumers was also emphasized in the code of ethics for Russian journalists covering ethnic issues ${ }^{1}$, promulgated in 2013. The code draws attention to journalists' responsibility for transmitting incorrect and stereotypical images of ethnicities, as well as provoking ethnic conflicts through reports the public is exposed to.

The aforementioned data, although presented very briefly, show that Russian public generally has a wide access to a variety of reports about ethnic issues in current media. An interesting question to discuss in this respect would be whether Russian public is indeed exposed to these reports, judging by their own estimations.

Let us try to answer this question using the data collected during the survey. First, the majority of the respondents stated that they come across information about ethnic groups in Russian mainstream media from time to time (58.08\%), while the second biggest group is those who declared that they see such reports seldom $(23.06 \%)$. The answers to this question did not depend at all on respondents' age $\left(\mathrm{X}^{2}=12.18\right.$, degrees of freedom $\left.=6, P=0.07\right)$, but rather on the regions they live in $\left(\mathrm{X}^{2}=38.52\right.$, degrees of freedom $\left.=9, P<0.01\right)$; in general, users living in big cities, including Moscow, St. Petersburg, those with a population over 1 million, and those between 500,000 and 1 million tended to come across this information more often than those living in smaller cities.

Second, the analysis showed that the majority of respondents would prefer to receive more information about ethnic groups through mainstream media than they currently do. In total, 590 persons (56.35\%) chose "more" or "much more" for this question, while 252 persons $(24.07 \%)$ would rather receive less information on this topic than they do now. Having analyzed answers according to the criteria "region of living" and "age," we found similarity in all subgroups under discussion. Basically, regardless the region of living and age group, the number of respondents who would prefer to receive more information on ethnic groups is, on average, one or two times higher than the number of those who would rather receive less information on this topic. We failed to find any dependency of respondents' answers to this question on their region of living $\left(\mathrm{X}^{2}=13.05\right.$, degrees of freedom $\left.=10, P=0.22\right)$ or age $\left(\mathrm{X}^{2}=11.84\right.$, degrees of freedom $\left.=6, P=0.06\right)$.

Third, respondents' basic interest in learning more about ethnic communities through media channels does not depend at all on the regions of living $\left(\mathrm{X}^{2}=7.77\right.$, degrees of freedom $=15, P=0.93$ ). In each region, the number of respondents who would most likely or likely study this information was six or seven times bigger than those who would be unlikely do that, and three times bigger than the number of those who answered "probably." At the same time, the answers to this question depended on respondents' age $\left(\mathrm{X}^{2}=36.53\right.$, degrees of freedom $\left.=9, P<0.01\right)$. Thus, users belonging to the 25-44 and 45-64 age groups showed greater interest in reports about ethnic formations (62\% and $71 \%$ of respondents, respectively), while in the under- 24 and over- 65 groups, the number of those who were interested in receiving such news was lower: $45 \%$ and $57 \%$, respectively. 
Fourth, we tried to find out what kind of information about ethnic groups would most likely attract the public's attention. We found out that the majority of survey participants are interested in more than one aspect of other ethnic groups' lives: the total number of such respondents was 571 persons (54.54\%), while the number of those who chose only one aspect was considerably lower: 341 (32.57\%). Among those who chose only one, the majority showed interest in the history of ethnic groups (171 persons; 16.33\%). The second most popular answer turned out to be customs and traditions ( 80 persons; $7.64 \%$ ), and the third was values and moral codes (57 persons; 5.44\%). The respondents' interest in the history of Russian peoples is stably high regardless their region of living and age. Examining all possible answer combinations to this question is hardly possible in a short article like this one, but the history of Russian peoples was the most popular answer among those who chose several aspects too.

Lastly, we looked into the sources of information about ethnic groups that are most often used by survey participants. Suggested answers included print media, TV and radio programs, the Internet, friends, educational institutions (school, university), and "other." One can easily notice that the first three answers reflected the main spectrum of mass media (print, audiovisual, online), while the others were predominantly based on communication with other people (friends, colleagues, teachers, etc.). In such a way, the analysis of obtained results was meant to determine the main sources of information (mass media or external contacts with other people) that the survey participants used when receiving information about ethnic groups. As we found out, in most cases respondents preferred to get information about ethnic groups from the Internet (450 persons; $42.98 \%$ ). TV and radio programs was the second most popular answer (404 persons; $38.59 \%)$. We did not find any dependency of the answers to the question on the respondents' region of living $\left(\mathrm{X}^{2}=24.70\right.$, degrees of freedom $\left.=25, P=0.48\right)$. At the same time, it should be noted that respondents under 45 years old more often get this information from the Internet, while respondents over 45 years old choose audiovisual mass media (TV and radio programs) for this purpose. Print media are also more often used by respondents of older age: 33 persons $(3.15 \%)$ in the 45-64 age group received information about ethnic groups from print media, while in the 25-44 age group this type of media was chosen by 18 persons $(1.72 \%)$ only. Therefore, we can conclude that survey participants' belonging to a certain age group influenced their answers to this question $\left(X^{2}=26,18\right.$, degrees of freedom $=15, P=0.03$ ).

\section{Conclusion}

The study revealed that although the number of ethnic media, as well as the number of reports devoted to ethnic issues in mainstream media in modern Russia, is considerably high ${ }^{1}$, the public claims that it does not come across such information in media outlets often. The majority of survey participants showed interest in learning

When stating this, we rely on the statistical data retrieved from open online and offline sources, as well as empirical analyses previously carried out by other domestic and international scholars, and not the current research. 
more about ethnic groups through media channels, often choosing more than one aspects of their life they would be potentially interested in (with the history of ethnic groups being the most popular answer). If we look at the dependency of respondents' answers to the questionnaire on their age, region of living, we notice the following - generally quite predictable - trends: (a) respondents belonging to the 25-44 and 45-64 age groups showed greater interest in reports about ethnic issues than those who are considerably younger or older; (b) respondents under 45 years old more often get information on this topic from the Internet, while the respondents over 45 years old usually choose audiovisual mass media (TV and radio programs) for this purpose; (c) print media as a source of information about ethnic groups are more often used by older people. All in all, though, we failed to find any outstanding dependency trends between the aforementioned criteria and respondents' answers.

We may conclude that the public's exposure to reports about ethnic issues in mainstream media is currently rather high on a quantitative level (if we mean by quantitative level the number of ethnic media and reports on this topic in current mainstream media ${ }^{1}$ ), but it is lower on a qualitative one (by qualitative level we mean actual exposure to such reports, according to the respondents' own estimations). This fact makes the second stage of our research - revealing and discussing the impact such reports can and probably do have - on Russian public more interesting and acute.

In general, we believe that singling out both specifics of the public's exposure to information about ethnicities and the connection between this exposure and the public's attitudes toward ethnicities may be of interest when forming a strategy for the development and promotion of ethnic media in the Russian media market, as well as when considering a general strategy for building harmonious relationships between representatives of different ethnic groups of Russia and discussing the role mass media can play in these relationships.

Moreover, studies of the public's exposure to reports on ethnic topics can contribute to further elaboration of the agenda-setting, framing, and contact theories, revealing the positive and negative effects media can have on people, depending on the regularity of such exposure and the type of reports people are exposed to; the possible connection between personal characteristics such as age and region of living and the degree of the media's impact; the role of the media in creating attitudes toward other ethnicities in a multicultural society; and much more. As previous studies of both psychologists and media scholars (Robert \& Lichter, 1988; Williamson \& DeSouza, 2006; Asamen et al., 2008; Schemer, 2014, etc.) showed, people - especially young people — often consider mass media to be a reliable source of information and an accurate reflection of real life (Robert \& Lichter, 1988). In this case, the responsibility of mass media for transmitting unbiased images of different ethnicities, particularly in a multiethnic society such as the Russian one, grows significantly - both in terms of building harmonious interethnic

When stating this, we rely on the statistical data retrieved from open online and offline sources, as well as empirical analyses previously carried out by other domestic and international scholars, and not the current research. 
relations in the country in general and preventing conflicts happening on ethnic grounds. This said, the analysis of the public's access to reports about ethnic groups in mainstream media can help not only evaluate the general accessibility of such information for broad audiences using quantitative and qualitative parameters suggested in the current research (which can be of value, for instance, when discussing the popularity of such media and ways to develop them in the future) but also to understand the effects (psychological, cultural, moral, etc.) of reports about ethnic topics on people in a multiethnic society.

\section{Limitations}

When considering the results of this study, one should keep in mind that an online survey, although an easy, fast, and cost-efficient method of collecting data, has certain drawbacks, including, for example, a limited sampling and the remote way of conducting the survey. It is clear that certain groups of people are less likely to have Internet access and to respond to online questionnaires, which limits the sampling to those people who have Internet access and the digital skills to use it. A lack of a trained interviewer to clarify questions if needed can also possibly lead to less reliable data. Last but not least is that respondents may not feel encouraged to provide accurate, honest answers, and they may not feel comfortable providing answers that present themselves in an unfavorable manner either.

\section{References}

Abanes, M. S., Scheepers, P. L. H., \& Sterkens, C. (2014). Ethno-religious groups, identification, trust and social distance in the ethno-religiously stratified Philippines. Research in Social Stratification and Mobility, 37, 61-75. doi:10.1016/j.rssm.2014.02.001

Alesina, A., \& La Ferrara, E. (2002). Who trusts others? Journal of Public Economics, 85(2), 207234. Retrieved from http://www.journals.elsevier.com/journal-of-public-economics

Allport, G. W. (1979). The nature of prejudice: 25th anniversary edition. Basic Books.

Allwood, J., Traum, D., \& Jokinen, K. (2000). Cooperation, dialogue and ethics. International Journal of Human-Computer Studies, 53(6), 871-914. Retrieved from http://www.journals.elsevier.com/international-journal-of-human-computer-studies doi: 10.1006/ijhc.2000.0425

Asamen, J. K., Ellis, M. L., \& Berry G. L. (2008). The SAGE handbook of child development, multiculturalism, and media. Thousand Oaks, CA: SAGE Publications.

Bahry, D., Kosolapov, M., Kozyreva, P., \& Wilson, R. (2005). Ethnicity and trust: Evidence from Russia. American Political Science Review, 99(04), 521-532. doi: 10.1017/S0003055405051853

Bazhenova, E. Y., Serikov, A. V., Serikova, I. B., \& Stukalova, D. N. (2015). Conflict potential of interethnic relations and migration processes in the Russian regions: Ethnoinstitutional methodology of analyses. Asian Social Studies, 11(7). Retrieved from http://www.ccsenet. org/journal/index.php/ass/article/view/46417 doi: 10.5539/ass.v11n7p252

Contini, R. M. (2013). New generations and intercultural integration in a multi-ethnic society. Procedia-Social and Behavioral Sciences, 93, 1819-1829. doi: 10.1016/j.sbspro.2013.10.124

Dunas, D. V. (2011). Towards an anthropological theory of media communication research. World of Media. Journal of Russian Media and Journalism Studies, 88-107. Retrieved from http://worldofmedia.ru/volumes/2012 
Elchardus, M., \& Spruyt, B. (2014). Universalism and anti-Muslim sentiment. International Journal of Intercultural Relations, 38, 75-85. doi: 10.1016/j.ijintrel.2013.03.001

Freedman, P., \& Goldstein, K. (1999). Measuring media exposure and the effects of negative campaign ads. American Journal of Political Science, 43(4), 1189-1208. doi: 10.2307/2991823

Gilmanova, A. N. (2013). Razvitie dvujazychnoi sistemy SMI v polikulturnom subjekte Rossiiskoi Federatsii kak faktor natsionalnoi mediabezopasnosti [The development of a two-language media system in polycultural subject of the Russian Federation as a factor of national media security]. Vestnik Chelyabinskogo Gosudarstvennogo Universiteta [Chelyabinsk State University Bulletin], 21, 141-143. Retrieved from http://www.lib.csu.ru/vch/312/tog.pdf

Gladkova, A. A. (2013a). Cultural pluralism in Russian press: challenges and prospects of development. World of Media. Journal of Russian Media and Journalism Studies, 325-334. Retrieved from http://worldofmedia.ru/volumes/2012

Gladkova, A. A. (2013b). The role of television in cultivating the values of pluralism and cultural diversity in children. Psychology in Russia: State of the Art, 6. doi: 10.11621/pir.2013.0113

Gladkova, A. A. (2015). Linguistic and cultural diversity in Russian cyberspace: examining four ethnic groups online. Journal of Multicultural Discourses, 10(1), 49-66. doi: 10.1080/17447143. 2015.1011657

Gureeva, A. N. (2015). Sotsialnye seti kak mediakommunikatsionniy resurs upravleniya imidzhem rossiiskogo vuza [Social networks as a media communication resource for managing the image of a Russian higher education institution]. Mediascope, 1. Retrieved from http:// mediascope.ru/node/1674

Informatsionno-analiticheskie materialy k sovmestnomu zasedaniu Soveta pri Prezidente Rossiiskoi Federatsii po mezhnatsionalnym otnosheniyam i Soveta pri Prezidente Rossiiskoi Federatsii po russkomu yazyku [Research and information materials prepared for a joint meeting of the Presidential Council for Interethnic Relations of the Russian Federation and the Presidential Council for Russian Language of the Russian Federation]. (2015). Retrieved from http://www.kremlin.ru/events/president/news/49491

Ivanic, A., Bates, K., \& Somasundaram, T. (2014). The role of the accent in radio advertisements to ethnic audiences: does emphasizing ethnic stereotypes affect spokesperson credibility and purchase intention? Journal of Advertising Research, 54(4), 407-419. doi:10.2501/JAR54-4-407-419

Gundelach, B. (2014). In diversity we trust: the positive effect of ethnic diversity on out-group trust. Political Behavior, 36(1), 125-142. doi: 10.1007/s11109-013-9220-x

Kazakov, A. A. (2014). Setting the agenda: a view of Western communication scholars. World of Media. Journal of Russian Media and Journalism Studies, 60-74. Retrieved from http:// worldofmedia.ru/volumes/2013

Krahé, B., \& Busching, R. (2015). Breaking the vicious cycle of media violence use and aggression: a test of intervention effects over 30 months. Psychology of Violence, 5(2), 217-226. doi: $10.1037 / \mathrm{a} 0036627$

Loennqvist, J.-E., Konstabel, K., Lönnqvist, N., \& Verkasalo, M. (2014). Accuracy, consensus, in-group bias, and cultural frame shifting in the context of national character stereotypes. Journal of Social Psychology, 154(1), 40-58. Retrieved from http://www.ncbi.nlm.nih.gov/ pubmed/24689336 doi: 10.1080/00224545.2013.843500

Makeenko, M. I. (2007). Radioveschanie i televidenie SCHA v novom stoletii: struktura, ekonomika, strategii [American radio and TV in the new century: structure, economics, strategy]. Moscow: Moscow University Press. 
Malkova, V. K. (2007). "Ne dopuskaetsya razhiganie mezhnatsionalnoi rozni”. Kniga ob etnicheskoi zhurnalistike (iz opyta analiza rossiskoi pressy) ["Provoking interethnic conflicts is prohibited". Book on ethnic journalism (the analysis of Russian press)]. Moscow: Russian Academy of Science.

Matsaganis, M. D., Katz, V. S., \& Ball-Rokeach, S. J. (2011). Understanding ethnic media. Producers, consumers, and societies. Thousand Oaks, CA: SAGE.

McCombs, M. E., \& Shaw, D. L. (1972). The agenda-setting function of mass media. The Public Opinion Quarterly, 36(2), 176-187. doi:10.1086/267990

Minyar-Belorucheva, A. P., \& Pokrovskaya, M. E. (2012). Etnicheskiye stereotipy v sovremennom yazikovom prostranstve [Ethnic stereotypes in modern language world]. Natsionalniy psikhologichesky zhurnal [National Psychological Journal], 2(8), 90-94. Retrieved from http://www.psy.msu.ru/science/npj

Mishlanova, S. L., \& Sirotkina, T. A. (2013). Etnicheskiye stereotypy kak reprezentatsiya stepeni tolerantnosti zhiteley regiona [Ethnic stereotypes as representation of tolerance degree of the inhabitants in the region]. Istoricheskaya $i$ sotsialno-obrazovatelnaya mysl [Historical and Socioeducational Thought], 5(21), 272-276. Retrieved from http://www.hist-edu.ru/ hist/article/view/767

Obraztsova, A. Yu. (2014). Osobennosti mediapotrebleniya detei shkolnogo vozrasta (na primere goroda Uglich) [Specificity of school-aged children's media consumption (a case study of the city of Uglich)]. Mediascope, 4. Retrieved from http://mediascope.ru/node/1648

Osin, R. V., \& Konstantinov, V. V. (2014). Osobennosti otnosheniya k obrazu trudovogo migranta v SMI [Specifics of attitude towards migrant workers in mass media]. Gumanitarnye, sotsialno-ekonomicheskie i obschestvennye nauki [Humanitarian, Socioeconomic and Social Science], 9. Retrieved from http://www.online-science.ru

Petrova, E., Bonkalo, T., Orlova, E., Panarin I., \& Furman, Y. (2014). Ethnic auto-and heterostereotypes of representatives of the indigenous population and immigrants in the contemporary metropolis. Asian Social Science, 10(24). Retrieved from https://www.questia.com/ library/journal/1P3-3528712891/ethnic-auto-and-hetero-stereotypes-of-representatives

Robert, S., \& Lichter, L. (1988). Does TV shape ethnic images? Media \& Values, 43. Retrieved from http://www.medialit.org/reading-room/does-tv-shape-ethnic-images

Séguin,D., \& Klimek, V.(2015). Justfivemoreminutes please: electronicmedia use, sleep and behaviour in young children. Early Child Development and Care, 5. doi: 10.1080/03004430.2015.1071528

Schemer, C. (2014). Media effects on racial attitudes: evidence from a three-wave panel survey in a political campaign. International Journal of Public Opinion Research, 26(4), 531-542. doi: 10.1093/ijpor/edt041

Shulumba, B. V. (2013). SMI i etnichnost: ot yazyka vrazhdy k yazyku tolerantnosti [Mass media and ethnicity: from hate speech towards tolerance speech]. Sotsialno-gumanitarnye znaniya [Sociohumanitarian Knowledge], 5. Retrieved from http://socgum-zhurnal.ru

Ufkes, E. G., Otten, S., van der Zee, K. I., \& Giebels, E. (2012). Neighborhood conflicts: the role of social categorization. International Journal of Conflict Management, 23(3), 290-306. doi: $10.1108 / 10444061211248985$

Vartanova, E. L. (2005). Globalizatsiya SMI i mass-media Rossii [Mass Media Globalization and Mass Media of Russia]. Vestnik Moskovskogo Universiteta. Seriya 10. Zhurnalistika. [Moscow University Journalism Bulletin], 4, 9-25.

Vartanova, E. L. (2012). O neobkhodimosti modernizatsii kontseptsiy zhurnalistiki i SMI [On the necessity to modernize the concepts of journalism and mass media]. Vestnik Moskovskogo Universiteta. Seriya 10. Zhurnalistika. [Moscow University Journalism Bulletin], 1, 7-26. 
Verevkin, O. L. (2009). Stereotipy vospriyatiya etnicheskich grupp [Stereotypes in the perception of ethnic groups]. Monitoring obschestvennogo mneniya: Ekonomicheskiye i sotsialnyey peremeny [Public opinion monitoring: Economic and social change], 6(94). Retrieved from http://wciom.ru/books_magazines/zhurnal_monitoring

Ward, M., O'Loughlin, J., Bakke, K. \& Cao, X. (2006). Cooperation without trust in conflictridden societies: Survey results from Bosnia and the North Caucasus. Retrieved from http:// www.colorado.edu/ibs/waroutcomes/docs/MDWapsa2006.pdf

Weaver, D. H., McCombs, M. E., \& Shaw, D. L. (2004). Agenda-setting research: issues, attributes, and influences. In L.L. Kaid (Ed.), Handbook of political communication research. (pp. 257-282). Mahwah, New Jersey.

Williamson, A., \& DeSouza, R. (2006). Representing ethnic communities in the media. Aotearoa Ethnic Network Journal, 1(1). Retrieved from http://www.aen.org.nz/journal/1/1/williamson_desouza.html

Original manuscript received September 23, 2015

Revised manuscript accepted December 17, 2015

First published online March 30, 2016 